

\section{Neoclassical and technological catching-up as the channels of the real convergence process in the European Union}

Izabela Młynarzewska- Borowiec

Faculty of Economics and Law, University of Technology and Humanities in Radom, Radom, Poland

\begin{tabular}{ll}
\hline ARTICLE INFO & ABSTRACT \\
\hline Article History & Purpose: \\
& The purpose of the paper is to investigate the $\beta$-convergence process between European \\
Received 30 January 2017 & Union member states in the period 2000-2014 and identify channels of that process. The \\
JEL Classifications & paper attempts to illustrate if the investigated group of countries experienced convergence \\
F15, F43, C51 & because of capital accumulation, technological catching-up or via both mechanisms. \\
& Design/methodology/approach: \\
& The framework used to test the relative strength of neoclassical and technological \\
& catching-up as convergence driving forces combines the neoclassical and endogenous \\
& representations of the economic growth process. The tests are conducted with the use of \\
& cross- sectional as well as panel data analysis, including the proper methods of estimation. \\
& Findings: \\
& The paper provides evidence for the presence of the $\beta$-convergence process among \\
& European Union countries in the period 2000-2014. The obtained results confirmed that in \\
& the analysed period, both channels of convergence (neoclassical and technological) occurred \\
& in the group of 27 EU member states. The technological mechanism seemed to be more \\
& important than the neoclassical one, especially between the "new" EU countries. In the \\
& group of "old" EU members no evidence of technological channel convergence was found. \\
& The preliminary survey on the existence of productivity convergence in the analysed \\
groups confirmed its existence in the EU-27 and EU-12 group. Results for the EU-15 group & were ambiguous.
\end{tabular}

Research limitations/implications:

As the results obtained for the EU-15 group were slightly different depending on the research method used, in the future, it would be advisable to carry out an additional study using an alternative research method. Moreover, further research on these issues should be explored towards much more accurate analysis of the productivity convergence and its impact on the real convergence process in the analysed groups of countries.

Keywords:

real convergence process, European Union, capital accumulation, technological catching-up

\section{Originality/value}

The paper is an important step, giving direction to studies on determinants of the real convergence process in the EU. According to the obtained results, technological channel, not capital accumulation, is the driving force of the converge process in the European Union. It might be an important signal for the future convergence policy pursued at the national and European level. The policy concentrated on the dynamics of capital seems not to be effective enough to increase the speed of the convergence process between European Union member states in the future.

\section{Introduction}

Economic convergence is one of the main goals of the European Union integration process, referred to in all the EU treaties. Article 174 of the Treaty of Lisbon states that "The Community shall aim at reducing disparities between the levels of development of the various regions and the backwardness of the least favoured regions..." (EU Treaty of Lisbon, 2007). After 2004, a vast group of less-developed Central and Eastern European countries started their integration with relatively richer Western

${ }^{\dagger}$ Corresponding Author: Izabela Młynarzewska

Email: i.mlynarzewska@,uthrad.pl

DOI: 10.25103/ijbesar.102.01 
European countries. In the last 12 years, GDP per capita disparities between the EU member states have decreased, in other words, $\sigma$ - convergence has occurred. The key determinant of that process was undoubtedly the $\beta$-convergence process - the fact that the growth in GDP per capita has been on average higher in poorer, than in richer EU member states. The existence of a negative relationship between the initial GDP per worker and the pace of economic growth is a phenomenon confirmed in the majority of empirical studies of the convergence process in the European Union (e.g. Schadler, Mody, Abiad and Leigh (2006); Alexiadis and Alexandrakis (2008); Halmai and Vásáry (2010); Tatomir and Alexe (2011); Staňisić (2012); Grzelak and Kujaczyńska (2013); Rapacki and Próchniak (2014)).

The theoretical foundations of the idea that poorer countries catch-up with the rich ones derive from two alternative types of approach: neoclassical convergence (capital deepening) and technological catching-up. Neoclassical catching-up refers to the Solow-Swan growth model (1957). Its central hypothesis is that diminishing investment returns (decreasing marginal productivity of capital) slows the growth rate of a country as it approaches a steady state. It implies that richer economies (with shorter distance from the common steady-state) grow slower than poorer ones. The major aspect of that approach is to assume that all countries implement technology at the same rate. Consequently, it means that all the differences in country growth rates depend on countries' distances from the common steadystate and their rate of decrease of capital returns.

On the other hand, the technological catching-up approach suggests that a catching-up process should occur because poorer countries (followers) have capabilities to easily imitate and adopt technology of more advanced countries (leaders). This approach starts from the assumption of different technology levels and growth rates between countries. That alternative stream in convergence literature initially developed by Abramovitz (1986), Baumol (1986), Dowrick and Nguyen (1989) and then introduced in endogenous growth models of Romer (1990), Aghion and Howitt (1998), Howitt (2000), focuses on the fact that poor countries face a huge technology gap and, subject to their absorptive capabilities, can grow faster. Convergence tendencies arise because, although innovation tends to increase productivity and technological differences between countries, diffusion of technology tends to decrease them.

Despite the significant difference in assumptions between the two convergence mechanisms, it is difficult to empirically separate technological progress from capital deepening. In literature, the empirical tests on two alternative channels of convergence have often been conducted by means of the same econometric specification. In standard growth regressions, the initial level of GDP per capita used as explanatory variable may be interpreted both as a proxy for the level of capital (the distance of a country from its steady-state) and as a proxy for the level of technology (technological gap) in the economy. Thus, it's not clear how much of the convergence is due to technology diffusion rather than capital deepening of poorer countries. The necessity of solving that problem was noticed by Stockey (1994) and Temple (1999). However, the seminal approach to separately test the two possible convergence mechanisms was introduced by Rogers and Dowrick (2002). An alternative method to study these aspects was also proposed by Wong (2007) and Feyrer (2007).

Initial research on the importance of the individual channels in shaping the convergence process concerned mainly OECD countries and other countries belonging to the particular income groups. Dowrick and Rogers (2002) found the evidence for the significant role of both channels in the convergence process of 57 rich and poor countries between 1965 and 1990. Wong (2007), in a study of 23 OECD countries (including also EU Member States) and the sample of 70 high and low-developed economies in the period 1960-1985 confirmed a much greater relevance of technology channel in shaping the convergence process in both groups of countries. In turn, the convergence research at sectoral level in the group of 50 developed and developing countries in the period 1980-2000 conducted by Dal Bianco (2010) pointed to the varied importance of both channels for individual income groups. Capital accumulation was proven to be more important for well-developed countries, and technology channel- more crucial for developing countries.

Empirical surveys on the convergence mechanisms in the EU (especially in the enlarged EU) have so far been very limited. They have been conducted mainly at regional level, testing the role of technological progress in the convergence process. Paci and Pigliaru (2001), in a study of 109 regions of the European Union in the period 1980-1993 noted the importance of technological catchup in shaping the real convergence process. Alaxiadis and Korres (2010), using the regional data for the $27 \mathrm{EU}$ member states in the period 1995-2006, confirmed the hypothesis that the technological factor had a significant and positive effect on convergence in Europe. The role of both convergence channels was also tested in the surveys concerning Italian (Bianchi and Menegatti (2005), Scoppa (2013)) and Spanish (de la Fuente (2002)) regions.

The presented paper attempts to fill a gap in the research on the significance of the neoclassical and technological convergence channels with regard to $\mathrm{EU}$ member states. The aim of the paper is to investigate $\beta$ convergence between European Union member states in the period 2000-2014, and primarily identify channels of that process. The paper attempts to indicate if the investigated group of countries experienced convergence because of capital accumulation, technological catchingup or both mechanisms together. The framework used to test the relative strength of neoclassical and technological catching-up as convergence driving forces in European Union countries combines the neoclassical and endogenous representations of the economic growth process. The hypothesis of a common technology growth (from Solow's model) is mitigated and the technological catching-up hypothesis is adopted. The survey is based both on a theoretical model and empirical specification considering the two mentioned mechanisms.

The paper is organised as follows. The second part concerns the methodology of identifying convergence mechanisms from a theoretical and empirical point of view. In section 3, the data sources are presented, particularly the methodology of capital per worker and TFP calculation is explained. In section 4 , the empirical evidence regarding the convergence process between the EU members (EU-27, EU-15 and EU-12 groups) is provided. Section 5 details the results of tests for the 
importance of neoclassical and technological catching-up as the channels of the convergence process between the EU member states. Additionally, productivity convergence between the EU members (the relation between the initial levels of TFP and TFP growth) is investigated. The conclusion is presented in the final part of the paper.

\subsection{Neoclassical and technological catching-up: theoretical framework and empirical specification The production function in a closed economy can be} written as the Cobb-Douglass function:

$$
Y_{i t}=A_{t} K_{i t}^{\alpha} L_{i t}^{1-\alpha}
$$

where $Y_{i t}$ is the output, $A_{t}$ the level of technology (Total Factor Productivity level), $K_{i t}$ capital stock and $L_{i t}$ labour resources in country $i$, at time $t$. $\alpha$ is the output elasticity of capital, equal to the capital share of income under the assumption that production factors are paid their marginal product. Assuming constant returns to scale, and after dividing both sides of the previous equation by labour input, it can be transformed into the following:

$$
y_{i t}=A_{t} k_{i t}^{\alpha}
$$

where $y_{i t}$ is the output per worker and $k_{i t}$ capital per worker of country $i$.

According to Solow's model, capital stock is accumulated at a fixed rate $s_{i}$ and depreciates through time at a common rate $\delta$, labour grows at a constant rate $n_{\text {in }}$. Under the above assumptions, capital accumulation in country $i$ can be described by the following dynamic equation:

$$
\dot{k}_{l t}=s_{i} y_{i t}-\left(n_{i}+\delta\right) k_{i t}
$$

where the dot notation denotes the derivative of the capital stock with respect to time.

In the neoclassical model, a common country technology growth rate $g$ is assumed, where:

$$
A_{t}=A_{0} e^{g t}
$$

Differently, one assumes that the technology growth rate is different in particular countries, thus:

$$
A_{i t}=A_{0} e^{g_{i} t}
$$

The assumption about different technology growth rates $g_{i}$ is essential in the situation when the technological catching-up process is to be considered. The technological catching-up approach is connected with the existence of a technological leader and followers, and technology transfer between them. According to Dowrick and Rogers' (2002) specification, technology transfer increases technical progress of a follower in direct proportion to the logarithm of the technological gap at the beginning of the period. Thus, technological progress of country $i$ can be described by the following formula:

$$
g_{i}=\theta+\varphi \ln \left(\frac{A_{o}^{L}}{A_{i o}}\right)
$$

Coefficient $\theta$ is a constant term reflecting the countryspecific determinants of technological progress (e.g. institutions, policies influencing domestic rate of innovation). $A^{L}$ is the highest value of $A$ in the group of economies under examination (in the initial year of the analysed period), in other words, it is the level of technology of the lead country. Coefficient $\phi$ can be interpreted as the speed of technology diffusion due to the technological gap between the leader and follower country $i$.

Substituting equation (5) into (2), then differentiating it with respect of time and finally dividing it by $y_{i t}$, one obtained:

$$
\frac{y_{i t}}{y_{i t}}=\alpha \frac{\dot{k_{t t}}}{k_{i t}}+g_{i}
$$

Then, substituting formula (6) into (7) one gets the following equation:

$$
\frac{y_{i t}}{y_{i t}}=\alpha \frac{\dot{k_{i t}}}{k_{i t}}+\left(\theta+\varphi \ln \left(\frac{A_{o}^{L}}{A_{i 0}}\right)\right)
$$

Equation 8 represents two different catching-up channels. The first term on the right-hand side reflects the influence of capital accumulation on the economy's growth in output. Taking into account decreasing capital returns and equation 3 showing that capital accumulation is higher in poorer countries, we can conclude that poorer countries, with a lower level of capital per head, can grow faster than richer ones; thus, the neoclassical catching-up process appears.

The second term in the mentioned equation represents the influence of the technological gap on GDP per worker growth in the economy. The greater the technological gap between the leader and the follower, the higher the output growth in the follower country. In other words, an economy with a lower initial level of technology grows faster because the technological catching-up process occurs. Of course, the role of both mentioned channels in boosting the pace of particular countries' economic growth can be differentiated. Furthermore, they can work separately or together.

The above theoretical background is useful for building a proper econometric specification in order to conduct an empirical analysis concerning the comparison of the importance of neoclassical and technological catching-up in the convergence process between EU member states. Following Bianchi and Menegatii's (2005) approach, the role of the neoclassical and technological convergence mechanisms can be tested via two different econometric specifications.

The first specification combines a modified $\beta$ convergence equation (in which output is regressed on the initial level of output) and a model based on the traditional decomposition of economic growth (where growth in output is decomposed into contributions due to the growth in capital and technological progress).

The simplest absolute $\beta$-convergence test provided by Barro (1991) investigates the cross-country relation between the initial level of output per worker and the growth in output per worker in the examined period:

$$
\ln \left(\frac{y_{i t}}{y_{i o}}\right)=\alpha_{1}+\beta_{1} \ln \left(y_{i o}\right)+\varepsilon_{i t}
$$

The negative relation between the initial level of GDP per worker and its growth in the analysed period, 
reflected in coefficient $\beta$, means that poorer countries grow faster and the absolute $\beta$-convergence process exists in the analysed group of countries. In the above equation, the catching-up phenomenon is described by the initial level of output as the regressor. In order to distinguish the two types of the catching-up process (neoclassical and technological), a modification of equation (9) incorporating equation (2), (5) and the other theoretical statements is estimated:

$$
\ln \left(\frac{y_{i t}}{y_{i o}}\right)=\alpha_{2}+\beta_{2} \ln \left(k_{i o}\right)+\gamma_{2} \ln \left(\frac{A_{o}^{L}}{A_{i o}}\right)+\omega_{i t}
$$

The negative sign of statistically significant $\beta$ coefficient associated with the logarithm of initial capital per worker indicates that poorer countries in the analysed group exhibit faster growth in GDP per worker. It confirms that neoclassical capital deepening is a significant channel of convergence in the investigated group of countries.

The positive sign of statistically significant coefficient associated with the logarithm of the technological gap (measured as the distance between initial $A$ (TFP) level of country $i$ and technology level of the lead country in the group) indicates that less-developed countries, with a huge technological gap, converge to richer ones because they improve their technological level much faster due to technology transfer and imitation. It confirms that technological catching-up occurs as an important channel of the convergence process.

The above econometric specification called "informal growth regression" is the most popular technique used to study sources of economic growth in empirical surveys. However, the modified $\beta$-convergence regression including a group of variables affecting growth is not a direct consequence of the theoretical model (8). Taking into account the solution proposed by Dowrick and Rogers (2002), as well as Bianchi and Menegatii’s (2005) approach, the growth rate decomposition regression can be constructed and estimated. A modification of equation (2) so that $\ln \left(\mathrm{y}_{\mathrm{t}} / \mathrm{y}_{\mathrm{o}}\right)$ on the left- hand side is obtained and including equation (5) (with the assumption that the average growth rate of $A$ is substituted by the total growth of technology in the analysed period) results in the following formula:

$$
\ln \left(\frac{y_{i t}}{y_{i o}}\right)=\alpha \ln \left(\frac{k_{i t}}{k_{i o}}\right)+\left(\theta+\varphi \ln \left(\frac{A_{o}^{L}}{A_{i o}}\right)\right)
$$

Finally, the neoclassical and technological channels of convergence can be investigated by estimating the following econometric model:

$$
\ln \left(\frac{y_{i t}}{y_{i o}}\right)=\alpha_{3}+\beta_{3} \ln \left(\frac{k_{i t}}{k_{i o}}\right)+\gamma_{3} \ln \left(\frac{A_{o}^{L}}{A_{i o}}\right)+\vartheta_{i t}
$$

The positive value of the statistically significant coefficient $\beta_{s}$ indicates that the neoclassical channel of convergence works, as well as positive sign of $\gamma_{s}$ coefficient implies the significant importance of technological catching-up in shaping the convergence process.

\section{Data}

The dataset used in the empirical surveys includes variables observed at annual intervals in the period 20002014 for the group of 27 European Union countries: Belgium, Denmark, Germany, Ireland, Greece, Spain, France, Italy, Luxembourg, the Netherlands, Austria, Portugal, Finland, Sweden, the United Kingdom, Bulgaria, the Czech Republic, Estonia, Cyprus, Latvia, Lithuania, Hungary, Malta, Poland, Romania, Slovenia and the Slovak Republic. GDP data expressed in Purchasing Power Parity $\left(\Upsilon_{i t}\right)$ and total labour force data $\left(L_{i t}\right)$ in the mentioned countries were obtained from the WDI database (World Bank Development Indicators Database).

Direct measures of capital per worker and technology levels in particular countries are used in the analysis. The dataset on the physical capital stocks $\left(K_{i t}\right)$ as well as the levels of technology-TFP $\left(A_{i t}\right)$ for all the analysed countries in the period 2000- 2014 are not available in any macroeconomic statistical database. To obtain them, additional calculations and surveys had to be conducted.

Countries' physical capital stocks $\left(K_{i t}\right)$ in the period 2000-2014 were calculated through Mroczek and Tokarski's (2014) perpetual inventory method. For each of the analysed country, the growth in capital stock can be written as:

$$
\Delta K_{t}=I_{t}-\delta K_{t-1}
$$

where: $K_{r}$ - capital stock in year $t, I_{t}$ - total investment flow, $\delta \in(O, 1)$ - the rate of depreciation of physical capital, fixed usually at the level of $5 \%$.

Assuming that, the capital stock in time $t$ can be described via the following formula:

$$
K_{t}=I_{t}+(1-\delta) K_{t-1}
$$

Consequently, it leads to a more general relation between the capital stock and the annual value of investment in the economy that can be written as:

$$
K_{t}=\sum_{\tau=0}^{\infty}(1-\delta)^{\tau} I_{t-\tau}
$$

Because the expression $(1-\delta)^{\tau}$ is the element of decreasing geometric progression, and $I_{t}>I_{t-1}$, thus the expression $(1-\delta)^{\tau} \quad I_{t \tau}$ is also the element of decreasing geometric series. Under the above assumption, the approximate value of capital stock in a country in time $t$ can be expressed as:

$$
K_{t}=\sum_{\tau=0}^{\infty}(1-\delta)^{\tau} I_{t-\tau} \approx \sum_{\tau=0}^{n}(1-\delta)^{\tau} I_{t-\tau}(16)
$$

The longer the time of investment accumulation taken into account (greater number of years $n$ ), the more accurate the approximation of the total value of capital stock in time $t$ in economy.

The data on gross fixed capital formation (the measure of annual value of investment $I_{t}$ ) for all the analysed countries in the period 1991-2014 was obtained from the WDI database. It was used in formula (16) to calculate the value of capital stocks in the period 2000-2014. A 10-year period of investment accumulation $(n=9)$ and capital depreciation rate $\delta$ at the level of $5 \%$ were assumed in the formula. 
In order to estimate the level of technology $A_{i t}$ ("the rest of Solow" or TFP) in the analysed countries, the method applied by Tokarski (2008), which consists of determining the estimation of parameter $\alpha$ on the basis of a two-input Cobb-Douglas function (1), transformed into the following efficiency model:

$$
\ln \left(\frac{Y_{i t}}{L_{i t}}\right)=\ln A_{0}+g_{i} t+\alpha \ln \left(\frac{K_{i t}}{L_{i t}}\right)+\varepsilon_{i t}
$$

The expression indicates the logarithm of technology level in the analysed country $i$.

In order to include individual and time effects shaping, the level of technology in the particular countries, the proper method of estimation was implemented - the within estimator was used. The estimation of model (17) as the fixed effect model resulted in obtaining the value of coefficient $\alpha$ (see table 1 ).

Table 1: Estimation results of model (17); dependent variable $\ln \left(Y \mathrm{it} / \mathrm{L}_{\mathrm{it}}\right)$; within estimator

\begin{tabular}{|c|c|}
\hline $\begin{array}{c}\text { Variable/ } \\
\text { Model diagnostics }\end{array}$ & Coefficient \\
\hline $\ln A_{0}$ & $\begin{array}{c}6.18993 \\
(0.156507)^{* * * *}\end{array}$ \\
\hline$t_{1}$ & $\begin{array}{c}0.040283 \\
(0.0147873)^{* * *} *\end{array}$ \\
\hline$t_{2}$ & $\begin{array}{c}0.0818278 \\
(0.014813)^{* *}\end{array}$ \\
\hline$t_{3}$ & $\begin{array}{c}0.0897239 \\
(0.0149173)^{* * *}\end{array}$ \\
\hline$t_{4}$ & $\begin{array}{c}0.110245 \\
(0.0151469)^{* * * *}\end{array}$ \\
\hline $\mathrm{t}_{5}$ & $\begin{array}{c}0.125412 \\
(0.0154718)^{* * *}\end{array}$ \\
\hline $\mathrm{t}_{6}$ & $\begin{array}{c}0.175903 \\
(0.0159254)^{* * *} *\end{array}$ \\
\hline$t_{7}$ & $\begin{array}{c}0.194165 \\
(0.0167047)^{* * * *}\end{array}$ \\
\hline$t_{8}$ & $\begin{array}{c}0.193465 \\
(0.0175852)^{* * *}\end{array}$ \\
\hline $\mathrm{t}_{9}$ & $\begin{array}{c}0.13693 \\
(0.0180517)^{* * *}\end{array}$ \\
\hline$t_{10}$ & $\begin{array}{c}0.147799 \\
(0.0184573)^{* * *}\end{array}$ \\
\hline$t_{11}$ & $\begin{array}{c}0.171163 \\
(0.0189445)^{* * *}\end{array}$ \\
\hline $\mathrm{t}_{12}$ & $\begin{array}{c}0.166619 \\
(0.0192125)^{* * *}\end{array}$ \\
\hline $\mathrm{t}_{13}$ & $\begin{array}{c}0.173931 \\
(0.0194137)^{* * *} *\end{array}$ \\
\hline $\mathrm{t}_{14}$ & $\begin{array}{c}0.193445 \\
(0.0195435)^{* * *} *\end{array}$ \\
\hline
\end{tabular}

\begin{tabular}{|l|c|}
\hline $\ln \left(\mathrm{K}_{\mathrm{it}} / \mathrm{L}_{\mathrm{it}}\right)$ & \multicolumn{1}{|c|}{$\begin{array}{c}\mathbf{0 . 4 1 3 6 6 1} \\
(0.01475)^{* * *}\end{array}$} \\
\hline $\mathrm{LSDV} \mathrm{R}^{2}\left(\right.$ Within $\left.\mathrm{R}^{2}\right)$ & $0.987785(0.935734)$ \\
\hline $\begin{array}{l}\text { Number of } \\
\text { observations }\end{array}$ & 405 \\
\hline $\begin{array}{l}\text { Model diagnostics } \\
\text { test statistics } \\
\text { critical value } \\
\text { [p value] }\end{array}$ & $\begin{array}{l}77.4394 \\
1.80802 ; \\
{[4.39353 \mathrm{e}-131]}\end{array}$ \\
\hline
\end{tabular}

Source: own calculations using GRETL

Note:

Individual effects of particular countries were taken into consideration in the model but not calculated.

${ }^{1}$ Test $\mathrm{F}$ for diversification of the constant in groups.

Null hypothesis $\mathrm{H}_{\mathrm{o}}$ : groups have a common constant.

The numbers in brackets denote the value of standard error. ${ }^{*} * *$ means significance at $1 \%$.

The next stage of the analysis involved calculating the TFP values $\left(A_{i t}\right)$ specific to individual countries and years. They were calculated according to the following formula:

$$
A_{i t}=T F P_{i t=} \frac{\left(Y_{i t} / L_{i t}\right)}{\left(K_{i t} / L_{i t}\right)^{a}}
$$

where $a$ is the estimate of parameter $\alpha$ of model (17), amounting to 0.413661 .

\section{3. $\beta$-convergence process in the European Union in the period 2000- 2014}

Studies on the $\beta$-convergence processes can be conducted using averaged data for the entire period or panel data. Taking into account the most traditional method based on averaged data, one should be aware that a limited number of observations influence the statistical credibility of the obtained results. However, from the economical point of view, the mentioned approach seems to be adequate, because it gives an opportunity to investigate the relation between initial conditions of economies and their long-run growth processes. On the other hand, due to taking into account a large number of observations and various methods of estimation, it may be said that studies based on panel data are more solid. From the economic point of view, an analysis that uses that kind of data is distorted by the influence of business cycles and other irregular fluctuations of the economy. Besides, it is hard to expect that growth in GDP per capita (per worker) in time $t$ is created by its level in time $t-1$. From the economic point of view, a good solution may be analysis based on data averaged for subperiods. In this case, the relation between the initial level of GDP and mid-term pace of economic growth can be investigated.

The survey on the convergence process between European Union countries in the period 2000- 2014 is conducted with the use of averaged data for the entire period and panel data. In the panel analyses, three subperiods: 2000-2004, 2005-2009 and 2010-2014 were taken into account. Furthermore, the analyses concern not only the entire group of 27 countries, but also the 
group of 15 "old" EU members states, and the group of 12 "new" member states.

In table 2 the estimation of structural parameters of equation (9) using averaged data for the period from 2000 to 2014 is included. White's test for heteroscedasticity for growth regression models was conducted in order to confirm that the OLS estimator is efficient and unbiased. The results of the conducted tests were satisfactory.

The results indicate the presence of the $\beta$-convergence process in the EU-27, in the analysed period. The negative value of the statistically-significant structural parameter $\beta_{1}$ of the equation (9) indicates a negative correlation between the initial level of income per worker (in 2000) and economic growth rate in the period of 20002014.

Table 2: Estimation results of the cross-sectional growth regression models describing absolute $\beta$ convergence among European Union Member States in the period 2000-2014; OLS method of estimation

\begin{tabular}{|c|c|c|c|}
\hline $\begin{array}{l}\text { Coefficient } \\
\text { / model } \\
\text { diagnostics }\end{array}$ & EU-27 & EU-12 & EU-15 \\
\hline$\alpha_{1}$ & $\begin{array}{l}4.90688 \\
(0.54509)^{* *} \\
*\end{array}$ & $\begin{array}{l}7.47519 \\
(0.85834)^{* *} \\
*\end{array}$ & $\begin{array}{l}0.0611445 \\
(0.66251)\end{array}$ \\
\hline$\beta_{1}$ & $\begin{array}{l}-0.412030 \\
(0.05150)^{* * *} \\
*\end{array}$ & $\begin{array}{l}-0.667023 \\
(0.08515)^{* *} \\
*\end{array}$ & $\begin{array}{l}0.0298116 \\
(0.06007)\end{array}$ \\
\hline $\mathrm{R}^{2}$ & 0.719119 & 0.859865 & 0.513045 \\
\hline $\begin{array}{l}\text { Adjusted } \\
\mathrm{R}^{2}\end{array}$ & 0.707883 & 0.845851 & 0.462875 \\
\hline $\begin{array}{l}\beta \\
\text { convergenc } \\
\text { e }\end{array}$ & yes & yes & no \\
\hline $\begin{array}{l}\beta \\
\text { coefficient }\end{array}$ & 0.01967 & 0.040729 & - \\
\hline $\begin{array}{l}\text { Number of } \\
\text { observation } \\
\mathrm{s}\end{array}$ & 27 & 12 & 15 \\
\hline $\begin{array}{l}\text { Model } \\
\text { diagnostics }{ }^{1} \\
: \\
\text { test } \\
\text { statistics } \\
\text { critical } \\
\text { value } \\
\text { [p value] }\end{array}$ & $\begin{array}{l}9.022542 \\
9.21034 \\
{[0.010984]}\end{array}$ & $\begin{array}{l}0.19373 \\
9.21034 \\
{[0.907679]}\end{array}$ & $\begin{array}{l}0.199245 \\
9.21034 \\
{[0.905179} \\
]\end{array}$ \\
\hline
\end{tabular}

Source: own calculations using GRET

Note:

The numbers in brackets denote the value of standard error. ***means significance at $1 \%$.

${ }^{1}$ White's test: null hypothesis $\mathrm{H}_{\mathrm{o}}$ : variance of error term is constant across observations (heteroscedasticity does not occur).
The speed of convergence ( $\beta$ coefficient) is calculated using the following formula:

$$
\beta=-\ln \left(1+\beta_{1}\right) / T
$$

(where $\mathrm{T}$ is the interval between the first and the last observation) and amounts to $1.9 \%$.

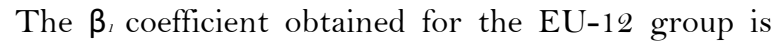
statistically significant and its negative sign stands for the existence of the convergence process between the "new" EU members. In the analysed period, the countries with lower GDP per worker approached the level of prosperity of richer ones at the relatively high rate of $4.07 \%$ per year.

According to the results included in table $2, \beta_{t}$ coefficient obtained for EU-15 is positive and statisticallyinsignificant. It means that the divergence process between the "old" EU members exists.

The above statements are also confirmed by the results of the estimation of equation (9) with the use of panel data (sub-periods: 2000-2004, 2005-2009 and 20102014). For each model the Breusch-Pagan test for the presence of individual effects was conducted. Additionally, for the first model (EU-27 group) the test for diversification of the constant in groups, confirming a viable use of the within estimator, was used. 
Table 3: Estimation results of panel growth regression models describing absolute $\beta$ - convergence in the period 2000-2014 among European Union Member States

\begin{tabular}{|c|c|c|c|}
\hline $\begin{array}{l}\text { Coefficient / model } \\
\text { diagnostics }\end{array}$ & $\mathrm{EU}-27$ & EU-12 & EU-15 \\
\hline$\alpha_{1}$ & $\begin{array}{l}3.03499 \\
(0.38513)^{* * * *}\end{array}$ & $\begin{array}{l}2.95965 \\
(0.34442)^{* * * *}\end{array}$ & $\begin{array}{l}0.574810 \\
(0.32835)^{*}\end{array}$ \\
\hline$\beta_{1}$ & $\begin{array}{l}-0.266316 \\
(0.03563)^{* * *}\end{array}$ & $\begin{array}{l}-0.283873 \\
(0.03308)^{* * *} *\end{array}$ & $\begin{array}{l}-0.041655 \\
(0.02950)\end{array}$ \\
\hline $\mathrm{LSDV} \mathrm{R}^{2}$ & 0.752043 & - & - \\
\hline Within $\mathrm{R}^{2}$ & 0.513136 & - & - \\
\hline $\mathrm{R}^{2}$ & - & 0.651734 & 0.444327 \\
\hline Adjusted $\mathrm{R}^{2}$ & - & 0.641491 & 0.422102 \\
\hline$\beta$ convergence & yes & yes & no \\
\hline$\beta$ coefficient & 0.020645 & 0.02226 & - \\
\hline Number of observations & 81 & 36 & 45 \\
\hline Estimator & within & OLS & OLS \\
\hline $\begin{array}{l}\text { Model diagnostics } \\
\text { test statistics } \\
\text { critical value } \\
\text { [p value] }\end{array}$ & $\begin{array}{l}1.98^{1} \\
1.705 \\
{[0,017348]}\end{array}$ & $\begin{array}{l}0.0625686^{2} \\
6.6349 \\
{[0,802481]}\end{array}$ & $\begin{array}{l}3.19675^{2} \\
6.6349 \\
{[0,07378]}\end{array}$ \\
\hline
\end{tabular}

Source: own calculations using GRETL

Note:

${ }^{1}$ Test $\mathrm{F}$ for diversification of the constant in groups null hypothesis $\mathrm{H}_{\mathrm{o}}$ : the groups have a common constant; rejection of $\mathrm{H}_{\mathrm{o}}$ means a viable use of the fixed effect model.

${ }^{2}$ Breusch-Pagan test: null hypothesis $\mathrm{H}_{\mathrm{o}}$ : Error variance in a unit $=\mathrm{O}$; rejection of $\mathrm{H}_{0}$ means that the introduction of individual effects is desirable; no possibility of using the OLS.

According to the obtained results, the absolute convergence process existed in the entire group of 27 countries as well as in the group of the "new" and relatively less-developed countries. In models constructed for the mentioned groups, the negative and

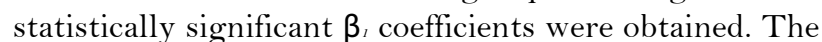
speed of the convergence process amounted to $2 \%$ and $2.2 \%$ respectively. In the light of the results included in table 3 , the convergence process did not exist in the group of the most developed EU members $\left(\beta_{t}\right.$ coefficient was positive and insignificant from the statistical point of view).

4. The tests for the existence of neoclassical and technological catching-up in European Union member states in the period 2000- 2014

The existence of capital deepening and technological catching-up mechanisms of convergence in the EU-27, EU-15 and EU-12 groups were verified, at first, through the estimation of equation (10), and then through the estimation of structural parameters of equation (12). The surveys were conducted with the use of cross-sectional as well as panel data analysis (a panel with three five-year subperiods for each country). The OLS estimator was employed to estimate the structural parameters of the cross-sectional regressions. In order to confirm that the OLS estimator was efficient and unbiased, model diagnostic procedures (White's test for heteroscedasticity and the Jarque Berra normality test) were conducted. The results of the mentioned tests were satisfactory (see table 4 and 6). The estimation technique of panel data regressions was employed after conducting the BreuschPagan test. The results suggested the absence of individual effects and the use of OLS estimator in all the analysed models (see table 5 and 7 ).

The coefficient estimates of the variables in model (10) with averaged data for the particular groups of countries are included in table 4 . The negative and statistically significant $\beta_{2}$ coefficients (for the initial level of capital per worker) in models constructed for the EU-27 and EU-12 groups imply that the neoclassical catching-up process occurs.

Table 4: Neoclassical and technological catching-up in $\beta$-convergence cross-sectional regressions for UE27, EU-15 and EU-12 in the period 2000-2014; equation (10); OLS method of estimation

\begin{tabular}{|l|l|l|l|}
\hline $\begin{array}{l}\text { Coefficient } \\
/\end{array}$ & UE-27 & UE-15 & UE-12 \\
\hline
\end{tabular}




\begin{tabular}{|c|c|c|c|}
\hline $\begin{array}{l}\text { Model } \\
\text { diagnostics }\end{array}$ & & & \\
\hline$\alpha_{2}$ & $\begin{array}{l}0.193124 \\
(1.29176)\end{array}$ & $\begin{array}{l}-1.34998 \\
(1.25811)\end{array}$ & $\begin{array}{l}-1.57064 \\
(1.86802)\end{array}$ \\
\hline$\beta_{2}$ & $\begin{array}{l}-0.199785 \\
(0.03252)^{* *} \\
*\end{array}$ & $\begin{array}{l}0.0655704 \\
(0.07484)\end{array}$ & $\begin{array}{l}-0.252496 \\
(0.05327)^{* *} \\
*\end{array}$ \\
\hline$\gamma_{2}$ & $\begin{array}{l}0.411038 \\
(0.17707)^{* *}\end{array}$ & $\begin{array}{l}0.168218 \\
(0.13477)\end{array}$ & $\begin{array}{l}0.781068 \\
(0.26292)^{* *}\end{array}$ \\
\hline $\begin{array}{l}\mathrm{R}^{2} \\
\text { Adj. } \mathrm{R}^{2}\end{array}$ & $\begin{array}{l}0.795891 \\
0.778142\end{array}$ & $\begin{array}{l}0.654109 \\
0.580311\end{array}$ & $\begin{array}{l}0.847465 \\
0.813568\end{array}$ \\
\hline Obs. & 27 & 15 & 12 \\
\hline $\begin{array}{l}\text { Model } \\
\text { diagnostics } \\
: \\
\text { White 's } \\
\text { test: } \\
\text { test } \\
\text { statistics } \\
\text { critical } \\
\text { value } \\
\text { [p value] } \\
\text { JB } \\
\text { normality } \\
\text { test: } \\
\text { test } \\
\text { statistics } \\
\text { critical } \\
\text { value } \\
\text { [p value] }\end{array}$ & $\begin{array}{l}3.69773 \\
15.0863 \\
{[0.593702]} \\
\\
2.89081 \\
9.21034 \\
{[0.23565]}\end{array}$ & $\begin{array}{l}13.5208 \\
15.0863 \\
{[0.018957} \\
] \\
\\
2.79577 \\
9.21034 \\
{[0.247119} \\
]\end{array}$ & $\begin{array}{l}4.39821 \\
15.0863 \\
{[0.493618]} \\
\\
9.13273 \\
9.2103 \\
{[0.056968]}\end{array}$ \\
\hline
\end{tabular}

Source: own calculations using GRETL

Note:

White 's test :Null hypothesis $H_{\mathrm{o}}$ : variance of error term is constant across observations (heteroscedasticity does not occur).

JB normality test: Null hypothesis $\mathrm{H}_{\mathrm{o}}$ : residuals are normally distributed.

****/**means significance at $1 \%, 5 \%$; the numbers in brackets denote the value of standard error.

Furthermore, the positive and significant $\gamma_{2}$ coefficients (for the initial technological gap) stand for the presence of technological catching-up between the countries in the mentioned groups. Taking into account the values of the obtained coefficient estimates, one may conjecture that the technological channel of convergence in EU-27 and EU-12 is much more important.

According to the results shown in table 4, neither the neoclassical nor technological mechanism works in the group of the "former 15 ". $\beta_{2}$ and $\gamma_{2}$ coefficients in the model for the EU-15 group are statistically-insignificant.

Table 5 summarises the parameter estimates of model (10) with the use of panel data. In the models made for EU-27 and EU-15, $\beta_{2}$ coefficients are negative and statistically-significant. $\gamma_{2}$ parameters are also significant but positive. It means that both (neoclassical and technological) catching-up mechanisms have occurred between countries of the above groups.
Table 5: Neoclassical and technological catching-up in $\beta$-convergence panel regressions for UE-27, EU-15 and EU-12 in the period 2000-2014; equation (10); OLS method of estimation

\begin{tabular}{|c|c|c|c|}
\hline $\begin{array}{l}\text { Coefficient } \\
\text { / } \\
\text { Model } \\
\text { diagnostics }\end{array}$ & $\mathrm{UE}-27$ & UE-15 & UE-12 \\
\hline$\alpha_{2}$ & $\begin{array}{l}0.88612 \\
(0.40271)^{* *}\end{array}$ & $\begin{array}{l}1.27101 \\
(0.487491)^{*} \\
*\end{array}$ & $\begin{array}{l}0.187024 \\
(0.60885)\end{array}$ \\
\hline$\beta_{2}$ & $\begin{array}{l}-0.0931004 \\
(0.01064)^{* *} \\
*\end{array}$ & $\begin{array}{l}-0.0724024 \\
(0.02727)^{* *}\end{array}$ & $\begin{array}{l}-0.12766 \\
(0.01881)^{* *} \\
\text { * }\end{array}$ \\
\hline$\gamma_{2}$ & $\begin{array}{l}0.0474433 \\
(0.03347)^{*}\end{array}$ & $\begin{array}{l}-0.0551467 \\
(0.06457)\end{array}$ & $\begin{array}{l}0.217491 \\
(0.09261)^{* *}\end{array}$ \\
\hline $\begin{array}{l}\mathrm{R}^{2} \\
\mathrm{Adj} . \mathrm{R}^{2}\end{array}$ & $\begin{array}{l}0.557998 \\
0.546212\end{array}$ & $\begin{array}{l}0.469383 \\
0.426787\end{array}$ & $\begin{array}{l}0.620632 \\
0.597640\end{array}$ \\
\hline Obs. & 81 & 45 & 36 \\
\hline $\begin{array}{l}\text { Model } \\
\text { diagnostics } \\
\text { : } \\
\text { Breusch- } \\
\text { Pagan test: } \\
\text { test } \\
\text { statistics } \\
\text { critical } \\
\text { value } \\
\text { [p value] }\end{array}$ & $\begin{array}{l}0.00097485 \\
6.6349 \\
{[0.975092]}\end{array}$ & $\begin{array}{l}0.847411 \\
6.6349 \\
{[0.357286]}\end{array}$ & $\begin{array}{l}0.00353216 \\
6.6349 \\
{[0.952608]}\end{array}$ \\
\hline
\end{tabular}

Source: own calculations using GRETL

Note:

Breusch-Pagan test: Null hypothesis $\mathrm{H}_{\mathrm{o}}$ : Error variance in a unit $=0$; rejection of $\mathrm{H}_{0}$ means that the introduction of individual effects is desirable; no possibility of using the OLS.

*******/*means significance at $1 \%, 5 \%, 10 \%$; the numbers in brackets denote the value of standard error.

Contrary to the result obtained in the cross-sectional regressions, in the panel model built for EU-15, a weak but statistically significant negative correlation between the initial level of capital per worker and GDP per worker growth is found ( $\beta_{2}$ parameter amounts to -0,072). However, the $\gamma_{2}$ coefficient estimated as negative and insignificant results in the absence of the technological mechanism of the convergence process.

The second test for validity of the two alternative channels of convergence in the EU is connected with the estimation of model (12), explained in section 1 . Table 6 shows the results of cross-sectional regressions. In models for EU-27 and EU-12, the positive value of $\beta_{s}$ parameters, confirms the presence of the catching-up process due to diminishing returns to capital. The positive and statistically-significant $\gamma_{s}$ coefficients, amounting to respectively 0.46 and 0.54 , indicate that technological catching-up due to technology flows is present. 
Table 6: Neoclassical and technological catching-up in growth rate decomposition cross-sectional regressions for UE-27, EU-15 and EU-12 in the period 2000-2014; equation (12);

OLS method of estimation

\begin{tabular}{|c|c|c|c|}
\hline $\begin{array}{l}\text { Coefficient / } \\
\text { Model diagnostics }\end{array}$ & UE-27 & UE-15 & UE-12 \\
\hline$\alpha_{3}$ & $\begin{array}{l}-2.58442 \\
(0.71961)^{* * *}\end{array}$ & $\begin{array}{l}-1.22873 \\
(0.87674)\end{array}$ & $\begin{array}{l}-3.05834 \\
(1.66179)^{*}\end{array}$ \\
\hline$\beta_{3}$ & $\begin{array}{l}0.396352 \\
(0.04211)^{* * *} *\end{array}$ & $\begin{array}{l}0.192976 \\
(0.12443)\end{array}$ & $\begin{array}{l}0.381943 \\
(0.07864)^{* * * *}\end{array}$ \\
\hline$\gamma_{3}$ & $\begin{array}{l}0.46539 \\
(0.12281)^{* * *} *\end{array}$ & $\begin{array}{l}0.254436 \\
(0.14215)\end{array}$ & $\begin{array}{l}0.547068 \\
(0.28036)^{*}\end{array}$ \\
\hline $\begin{array}{l}\mathrm{R}^{2} \\
\text { Adj. } \mathrm{R}^{2}\end{array}$ & $\begin{array}{l}0.88891 \\
0.87925\end{array}$ & $\begin{array}{l}0.65744 \\
0.52243\end{array}$ & $\begin{array}{l}0.85275 \\
0.82002\end{array}$ \\
\hline Obs. & 27 & 15 & 12 \\
\hline $\begin{array}{l}\text { Model diagnostics: } \\
\text { White 's test: } \\
\text { test statistics } \\
\text { critical value } \\
\text { [p value] } \\
\text { JB normality test: } \\
\text { test statistics } \\
\text { critical value } \\
\text { [p value] }\end{array}$ & $\begin{array}{l}6.7114 \\
15.086 \\
0.2430 \\
\\
\\
0.6494 \\
9.210 \\
{[0.7227]}\end{array}$ & $\begin{array}{l}0.9732 \\
9.210 \\
{[0.6147]}\end{array}$ & $\begin{array}{l}1.3114 \\
9.210 \\
{[0.5191]}\end{array}$ \\
\hline
\end{tabular}

Source: own calculations using GRETL

Note:

White 's test: Null hypothesis $\mathrm{H}_{\mathrm{o}}$ : variance of error term is constant across observations JB normality test: Null hypothesis $\mathrm{H}_{\mathrm{o}}$ : residuals are normally distributed.

*****means significance at $1 \%, 10 \%$; the numbers in brackets denote the value of standard error.

The coefficient estimates obtained in the model for EU-15 have positive signs, but they are insignificant from the statistical point-of-view. Thus, one can conjecture that none of the analysed convergence mechanisms works between the most developed EU members. In turn, the results obtained in the panel data version of model (12) reject the hypothesis of technological catching-up as a determinant of the convergence process, while they confirm the positive and statistically significant influence of capital deepening on the convergence process between them (see table 7).

Table 7: Neoclassical and technological catching-up in growth rate decomposition panel regressions for UE27, EU-15 and EU-12 in the period 2000-2014; equation (12);

OLS method of estimation

\begin{tabular}{|l|l|l|l|}
\hline $\begin{array}{l}\text { Coefficient / } \\
\text { Model diagnostics }\end{array}$ & UE-27 & UE-15 & UE-12 \\
\hline$\alpha_{3}$ & $\begin{array}{l}-0.98956 \\
(0.32901)^{* * *}\end{array}$ & $\begin{array}{l}-0.249749 \\
(0.38777)\end{array}$ & $\begin{array}{l}-1.36871 \\
(0.66816)^{* *}\end{array}$ \\
\hline$\beta_{3}$ & $\begin{array}{l}0.354627 \\
(0.04177)^{* * *}\end{array}$ & $\begin{array}{l}0.299799 \\
(0.07154)^{* * *} *\end{array}$ & $\begin{array}{l}0.333278 \\
(0.06904)^{* * * *}\end{array}$ \\
\hline$\gamma_{3}$ & $\begin{array}{l}0.175978 \\
(0.05477)^{* * *}\end{array}$ & $\begin{array}{l}0.0524655 \\
(0.06425)\end{array}$ & $\begin{array}{l}0.240265 \\
(0.10957)^{* *}\end{array}$ \\
\hline
\end{tabular}




\begin{tabular}{|c|c|c|c|}
\hline $\begin{array}{l}\mathrm{R}^{2} \\
\text { Adj. } \mathrm{R}^{2}\end{array}$ & $\begin{array}{l}0.544679 \\
0.532537\end{array}$ & $\begin{array}{l}0.323755 \\
0.289075\end{array}$ & $\begin{array}{l}0.467254 \\
0.434966\end{array}$ \\
\hline Obs. & 81 & 45 & 36 \\
\hline $\begin{array}{l}\text { Model diagnostics: } \\
\text { Breusch-Pagan test: } \\
\text { test statistics } \\
\text { critical value } \\
\text { [p value] }\end{array}$ & $\begin{array}{l}5.12383 \\
6.6349 \\
{[0.02359]}\end{array}$ & $\begin{array}{l}4.98723 \\
6.6349 \\
{[0.025535]}\end{array}$ & $\begin{array}{l}1.53419 \\
6.6349 \\
{[0.215484]}\end{array}$ \\
\hline
\end{tabular}

Source: own calculations using GRETL

Note:

Breusch-Pagan test: Null hypothesis $\mathrm{H}_{\mathrm{o}}$ : Error variance in a unit = o; rejection of $\mathrm{H}_{\mathrm{o}}$ means that the introduction of individual effects is desirable; no possibility of using the OLS

********means significance at $1 \%, 5 \%$; the numbers in brackets denote the value of standard error

The growth rate decomposition panel regressions for the group of 27 and the "new" 12 countries are also built. The estimates support the previous statements that convergence process in the above groups of countries depends on capital accumulation, as well as on technological catching-up. Looking at the values of the parameter estimates, one can assume that technology transfers and technological gap as determinants of convergence are relatively more important in the EU-12 group.

The results of the above tests, regardless of the econometric specification and the type of data used in surveys, show that the technological channel is found as an important determinant of the convergence process in the entire group of analysed countries and between the "new' EU members, and it is totally insignificant in the EU-15 group. It leads to the conjecture that in the case of the EU-27 and EU-12 groups, technological progress is faster in economies with a relatively lower initial level of technology. In turn, technologically well-developed countries experience higher pace of technology growth than less-developed countries of the EU-15 group. To prove it, an additional simple survey on the existence of productivity convergence is conducted. It consists of an examination of the relation between the initial technology level and technological progress in the analysed groups of countries. Table 8 includes the estimation results of models with averaged and panel data.

The following regression is estimated:

$$
\ln \left(\frac{A_{i t}}{\text { Aio }}\right)=\vartheta+\theta \ln \left(A_{i o}\right)+\mu_{i t}
$$

The negative and statistically significant $\theta$ coefficient indicates the presence of productivity convergence.

Table 8: Initial TFP level and TFP growth in 20002014 for UE-27, EU-15 and EU-12; cross-sectional and panel data regressions; OLS method of estimation

\begin{tabular}{|l|l|l|l|}
\hline $\begin{array}{l}\text { Coefficient } \\
/\end{array}$ & UE-27 & UE-15 & UE-12 \\
Model \\
diagnostic \\
$\mathrm{s}$
\end{tabular}

\begin{tabular}{|c|c|c|c|}
\hline \multicolumn{4}{|c|}{ cross-sectional regression } \\
\hline$u$ & $\begin{array}{l}2.29993 \\
(0.64394) * * *\end{array}$ & $\begin{array}{l}1.0876 \\
(0.86672)\end{array}$ & $\begin{array}{l}3.64275 \\
(1.3268)^{* *}\end{array}$ \\
\hline$\theta$ & $\begin{array}{l}-0.340309 \\
(0.10398)^{* * * *}\end{array}$ & $\begin{array}{l}-0.148432 \\
(0.13792)\end{array}$ & $\begin{array}{l}-0.559931 \\
(0.21835)^{*} *\end{array}$ \\
\hline $\begin{array}{l}\mathrm{R}^{2} \\
\mathrm{Adj} . \mathrm{R}^{2}\end{array}$ & $\begin{array}{l}0.399943 \\
0.371941\end{array}$ & $\begin{array}{l}0.281811 \\
0.211181\end{array}$ & $\begin{array}{l}0.396728 \\
0.336400\end{array}$ \\
\hline Obs. & 27 & 15 & 12 \\
\hline $\begin{array}{l}\text { Model } \\
\text { diagnostic } \\
\text { s: } \\
\text { White 's } \\
\text { test: } \\
\text { test } \\
\text { statistics } \\
\text { critical } \\
\text { value } \\
\text { [p value] } \\
\text { JB } \\
\text { normality } \\
\text { test: } \\
\text { test } \\
\text { statistics } \\
\text { critical } \\
\text { value } \\
\text { [p value] }\end{array}$ & $\begin{array}{l}8.06302 \\
9.21034 \\
0.0177475\end{array}$ & $\begin{array}{l}2.55279 \\
9.21034 \\
0.279041\end{array}$ & $\begin{array}{l}0.927622 \\
9.21034 \\
0.628882 \\
\\
1.20993 \\
9.21034 \\
0.546093\end{array}$ \\
\hline \multicolumn{4}{|c|}{ panel data regression } \\
\hline$u$ & $\begin{array}{l}1.25673 \\
(0.284642)^{* *} \\
*\end{array}$ & $\begin{array}{l}0.549331 \\
(0.29019)^{*}\end{array}$ & $\begin{array}{l}2.43497 \\
(0.590832)^{* *} \\
*\end{array}$ \\
\hline$\theta$ & $\begin{array}{l}-0.1912 \\
(0.045299)^{*} * \\
*\end{array}$ & $\begin{array}{l}- \\
0.0793251 \\
(0.045676) \\
*\end{array}$ & $\begin{array}{l}-0.382072 \\
(0.09537)^{* * *} *\end{array}$ \\
\hline $\begin{array}{l}\mathrm{R}^{2} \\
\text { Adj. } \mathrm{R}^{2}\end{array}$ & $\begin{array}{l}0.384010 \\
0.373681\end{array}$ & $\begin{array}{l}0.265544 \\
0.243812\end{array}$ & $\begin{array}{l}0.320683 \\
0.300703\end{array}$ \\
\hline
\end{tabular}




\begin{tabular}{|l|l|l|l|}
\hline Obs. & 81 & 45 & 36 \\
\hline $\begin{array}{l}\text { Model } \\
\text { diagnostic }\end{array}$ & & & \\
s: & & & \\
Breusch- & & & \\
Pagan & 1.47735 & 1.70594 & 0.038149 \\
test: & 6.6349 & 6.6349 & 6.6349 \\
test & 0.224189 & 0.191513 & 0.546093 \\
statistics & & & \\
critical & & & \\
value & & & \\
[p value] & & & \\
\hline
\end{tabular}

Note:

Source: own calculations using GRETL

White 's test: Null hypothesis $\mathrm{H}_{\mathrm{o}}$ : variance of error term is constant across observations (heteroscedasticity does not occur).

JB normality test: Null hypothesis $\mathrm{H}_{\mathrm{o}}$ : residuals are normally distributed.

Breusch-Pagan test: Null hypothesis $\mathrm{H}_{\mathrm{o}}$ : Error variance in a unit $=0$; rejection of $\mathrm{H}_{0}$ means that the introduction of individual effects is desirable; no possibility of using the OLS.

****/**/*means significance at $1 \%, 5 \%, 10 \%$; the numbers in brackets denote the value of standard error.

Regardless of the type of data taken into account, the obtained estimation results confirm that there is a statistically significant and negative correlation between the initial level of technology and technological progress in EU-2 7 group ( $\theta$ coefficient amounts to about -0.34 and -0.19 respectively). Additionally, one can remark that the mentioned negative relation is even stronger between the "new" member states ( $\theta$ coefficient amounts to about 0.56 and -0.38 respectively). In other words, the pace of productivity convergence between them is much higher than in the overall group of the analysed countries.

In turn, the estimates of the models built for the EU15 group indicate either the absence of productivity convergence ( $\theta$ coefficient is negative but statistically insignificant in the model based on averaged data) or the presence of a very weak negative relationship between the initial level of technology and the pace of technological progress $(\theta$ coefficient is estimated to be only -0.08 in the model based on panel data).

\section{Conclusion}

The paper provides evidence for the presence of the $\beta$ convergence process between European Union countries in the period 2000-2014. The conducted analysis clearly indicates that the catching-up process existed in the analysed group of 27 member states. Moreover, the speed of convergence was much stronger between 12 "new" members than in the entire group. However, a surprising aspect of it is that in the analysed period, the convergence between the most developed "old" EU countries did not exist. In other words, in the EU-15 group, the relatively poorer countries did not catch-up with the richer ones.

The paper aimed mainly at identifying the possible mechanisms responsible for generating the obtained convergence results. The conducted empirical surveys were focused on the neoclassical and technological catching-up mechanisms, proposed by the economic theory. The validity of the two alternative convergence driving forces was tested with the use of two different econometric specifications and two different types of data. The obtained results confirmed that both channels of convergence: neoclassical and technological occurred in the group of $27 \mathrm{EU}$ members. Moreover, the technological mechanism seemed to be more important than the neoclassical one. The mentioned phenomenon was particularly visible between the "new" EU countries. Regardless of the econometric specification, and the type of data used in surveys, the obtained results indicated that the $\beta$-convergence process between them was the result of differences in technology levels and technology transfer rather than capital accumulation.

The results obtained for the group of "old" EU members were ambiguous. No evidence for the existence of technological channel of convergence process in that group of countries was found. The estimation results of models based on averaged data denoted also the lack of the neoclassical mechanism, while estimations of panel models signalled the importance of capital deepening. Even though the last mechanism was found, it turned out not to be sufficient to influence the $\beta$-convergence process in the group of the most developed EU countries.

In general, one may conclude that the technological channel, not capital accumulation, is the driving force of the converge process in the European Union. The more intensive technological catching-up process, the higher the speed of $\beta$ - convergence. The above statement was also confirmed by the survey on the existence of productivity convergence between the analysed countries.

In the EU-27 and EU-12 groups, where productivity convergence appeared (technological progress was faster in the countries with relatively lower initial TFP level), the $\beta$-convergence process was found. It is worth adding that productivity convergence in the mentioned groups was a result of high diversity of technology levels and intensive technology transfer between countries. Moreover, medium-high technologies that are relatively easy to implement were mostly transferred.

In contrast, in the EU-15 group, where countries with higher productivity level experienced the highest technology progress, technological catching-up did not occur, and nor did the $\beta$-convergence process. One can suppose, that between the most developed EU countries having similar technology levels and small technological gaps, technology transfer was much less-intense (the implementation of high technologies requires specific absorptive capabilities, the most groundbreaking technologies are particularly protected, etc.).

The obtained results and insights about the sources of the convergence process in the European Union might be an important signal for the convergence policy pursued at the national and European level. The policy concentrated on the dynamics of capital seems to be not effective enough to increase the speed of the convergence process. Bearing in mind the key role of productivity convergence, the policy should move forward in the direction of deepening countries' absorptive and imitation capabilities, as well as supporting technology transfer.

This is an Open Access article distributed under the terms of the Creative Commons Attribution Licence

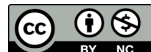




\section{References}

Abramovitz M., 1986, Catching up, Forging Ahead and Falling Behind, Journal of Economic History, Vol. 46, pp. 385-406

Aghion $P$, Howitt P., 1998, Endogenous Growth Theory, MIT Press, Cambridge

Alexiadis S., Alexandrakis A., 2008, Threshold Conditions' and Regional Convergence in European Agriculture, International Journal of Economic Sciences and Applied Research, Vol. 1, No.2, pp. 13-37

Alexiadis S., Korres G.M., 2010, Adoption of Technology and Regional Convergence in Europe, European Spatial Research and Policy, Vol.17, No.2, pp. 95-105

Barro R.J., 1991 Economic Growth in a cross section of countries, Quarterly Journal of Economics, Vol. 106, pp. 407-444

Barro R. J., Sala-i-Martin X., 1995, Economic Growth, McGraw-Hill, New York

Baumol W. J., 1986, Productivity Growth, Convergence and Welfare: What the Long-Run Data Show, American Economic Review, Vol.76, No.5, pp.10721085

Bianchi C., Menegatii M., 2005, Neoclassical versus Technological Convergence: An Empirical Analysis Applied to the Italian Regions, Working Paper No. 172, Dipartimento di economia politica e metodi quantitativi, Università di Pavia, ftp://economia.unipv.it/q172.pdf

Dal Bianco S., 2010, Technology Diffusion or Capital Accumulation? An Empirical Assessment of Convergence in Manufacturing, Working Paper No. 114, Dipartimento di economia politica e metodi quantitativi, Università di Pavia, http://economia.unipv.it/docs/dipeco/quad/ps/ReP Ec/pav/wpaper/q114.pdf

Dal Bianco S., 2010, New evidence on Classical and Technological Convergence in Manufacturing, Rivista italiana degli economisti: the journal of the Italian Economic Association, Vol. 15, No.2, pp.305336

Dowrick S., Nguyen D. T., 1989, OECD Comparative Economic Growth 1950-85: Catch up and Convergence, American Economic Review, Vol. 79, pp.1010-1030

Dowrick S. and Rogers M. ,2002, Classical and Technological Convergence: beyond the Solow-Swan Growth Model, Oxford Economic Papers, Vol.54, pp. 369-385

Feyrer J., 2007, Demographics and productivity, Review of Economics and Statistics, Vol. 89, No.1, pp. 100-109

De la Fuente A., 2002, On the sources of convergence: A close look at the Spanish regions, European Economic Review, Vol. 46, pp. 569-599

Grzelak A. and Kujaczyńska M., 2013, Real Convergence of the European Union Members States - Evaluation Attempt, Management, Vol. 17, pp. 393-404.

Halmai P. and Vásáry V., 2010, Real Convergence in the New Member States of the European Union, shorter and longer term prospects, The European Journal of Comparative Economics, Vol. 7, No. 1, pp. 229-253
Howitt P., 2000, Endogenous Growth and CrossCountries Income Differences, American Economic Review, Vol. 90, pp. 829-846

Kufel T., 2007, Ekonometria. Rozwiązywanie problemów z wykorzystaniem programu GRETL, PWN, Warszawa

Maddala S.G., 1992, Introduction to Econometrics, Macmillan Publishing Company, New York

Mroczek K., Tokarski T., 2014, Efekt grawitacyjny i techniczne uzbrojenie pracy a zróżnicowanie wydajności pracy w krajach UE, Studia PrawnoEkonomiczne, No. XCIII Vol.93, pp.245-259

Paci R., Pigliaru F.,2001, Technological catching-up and Regional Convergence in Europe, Working Paper CRENoS, No. 1999_09, pp.1-17

Rapacki R., Próchniak M., 2014, The Impact of EU Membership on Economic Growth and Real Convergence of the Central and Eastern European Countries, Ekonomia, Vol.39, pp.87-121

Romer P., 1990, Endogenous Technological Change, Journal of Political Economy, Vol.98, No.5, pp.71-102.

Schadler S., Mody A., Abiad A., Leigh D., 2006, Growth in the Central and Eastern European Countries of the European Union, IMF Occasional Paper, No.252

Scoppa V., 2013, Technological catch-up or neoclassical convergence? Identifying the channels of convergence for Italian regions, Economics and Business Letters, Vol. 2, No. 4, pp.169-181

Solow R. M., 1956, A Contribution to the Theory of Economic Growth, Quarterly Journal of Economics, Vol. 70, pp. 65-94

Staňisić N., 2012, The Effects of the Economic Crisis on Income Convergence in the European Union, Acta Oeconomica, Vol. 62, pp. 161-182

Stokey N., 1994, Sources of Economic growth: Comments on Barro-Lee, Carnegie Rochester Conference on Public Policy, Vol. 40, pp. 47-57

Swan T. W., 1956, Economic Growth and Capital Accumulation, Economic Record, Vol.32, pp. 334-361

Tatomir F.C., Alexe I., 2011, Laggards or Performers? CEE vs. PIIGS countries' catch-up with Euro Area in the last ten years, MPRA Paper, No.35715

Temple J., 1999, The New Growth Evidence, Journal of Economic Literature, Vol. 37, pp. 112-156

Tokarski T., 2008, Oszacowanie regionalnych funkcji produkcji, Wiadomości Statystyczne, Vol.10, pp. 3853

Tokarski T., 2010, Przestrzenne zróżnicowanie łącznej produktywności czynników produkcji w Polsce (The Regional Diversification of Total Factor Productivity in Poland), Gospodarka Narodowa, No. 3, pp. 23-38

Wong W., 2007, Economic growth: a channel decomposition exercise, The B.E. Journal of Macroeconomics, Vol. 7, No. 1, pp.1-38 